\title{
CORROSION OF DELTA PLUTONIUM BY SYNTHETIC SEA WATER
}

A. E. Hodges, III

\author{
J. M. Haschke
}

Chemistry Research and Development

PRODUCT INTEGRITY AND SURVEILLANCE

\section{Rockwell International Rocky Flats Plant P.O. Box 464 \\ Golden, Colorado 80401}

U. S. DEPARTMENT OF ENERGY CONTRACT DE-AC04-76DPO3533 


\section{DISCLAIMER}

This report was prepared as an account of work sponsored by an agency of the United States Government. Neither the United States Government nor any agency Thereof, nor any of their employees, makes any warranty, express or implied, or assumes any legal liability or responsibility for the accuracy, completeness, or usefulness of any information, apparatus, product, or process disclosed, or represents that its use would not infringe privately owned rights. Reference herein to any specific commercial product, process, or service by trade name, trademark, manufacturer, or otherwise does not necessarily constitute or imply its endorsement, recommendation, or favoring by the United States Government or any agency thereof. The views and opinions of authors expressed herein do not necessarily state or reflect those of the United States Government or any agency thereof. 


\section{DISCLAIMER}

Portions of this document may be illegible in electronic image products. Images are produced from the best available original document. 


\section{LEGAL NOTICE.}

I'his report was prepared as an account of work sponsored by the United States Government. Neither the United States nor the Department of Energy, nor any of their employees, nor any of their contractors, subcontractors, or their employees, makes any warranty, expressed or implied, or assumes any legal liability or responsibility for the accuracy, completenesss or usefulness of any information, apparatus, product or process disclosed, or represents that its use would not infringe privately owned rights.

Printed in the United States of America Available from the National Technical Information Service U. S. Department of Commerce Springfield, Virginia 22161

Price: Printed Copy $\$ 4.50$ Microfiche $\$ 3.00$

Price Is Subject to Change Without Notice 
Printed

October 24, 1979
RFP-2919

UC-71 TRANSPORTATION OF PROPERTY AND NUCLEAR MATERIALS

TIC-4500-(Rev. 67)

\section{CORROSION OF DELTA PLUTONIUM \\ BY SYNTHETIC SEA WATER}

A. E. Hodges, III

J. M. Haschke

Chemistry Research and Development PRODUCT INTEGRITY AND SURVEILLANLE

SUBJECT DESCRIPTORS

Corrosion Delta Plutonium Sea Water

\footnotetext{
ROCKWELL INTERNATIONAL

ENERGY SYSTEMS GROUP ROCKY FLATS PLANT

P.O. BOX 464

GOLDEN, COLORADO 80401
}

Prepared under Contract DE-AC04-76DPO3533

for the

Albuquerque Operations Office

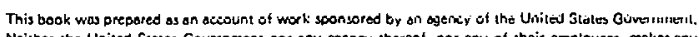
Neither the United States Government nor any aseney thereot. nor any of their employees, makes any warranty. express or implied. or assumes any legal liability or responsion process disclosed, of represents that its use would not infringe privately owned rights. Reterence herein to eny specific commercial product, process, or service by trade name, trademark, manufacturer, or otherwise, does 


\section{CONTENTS}

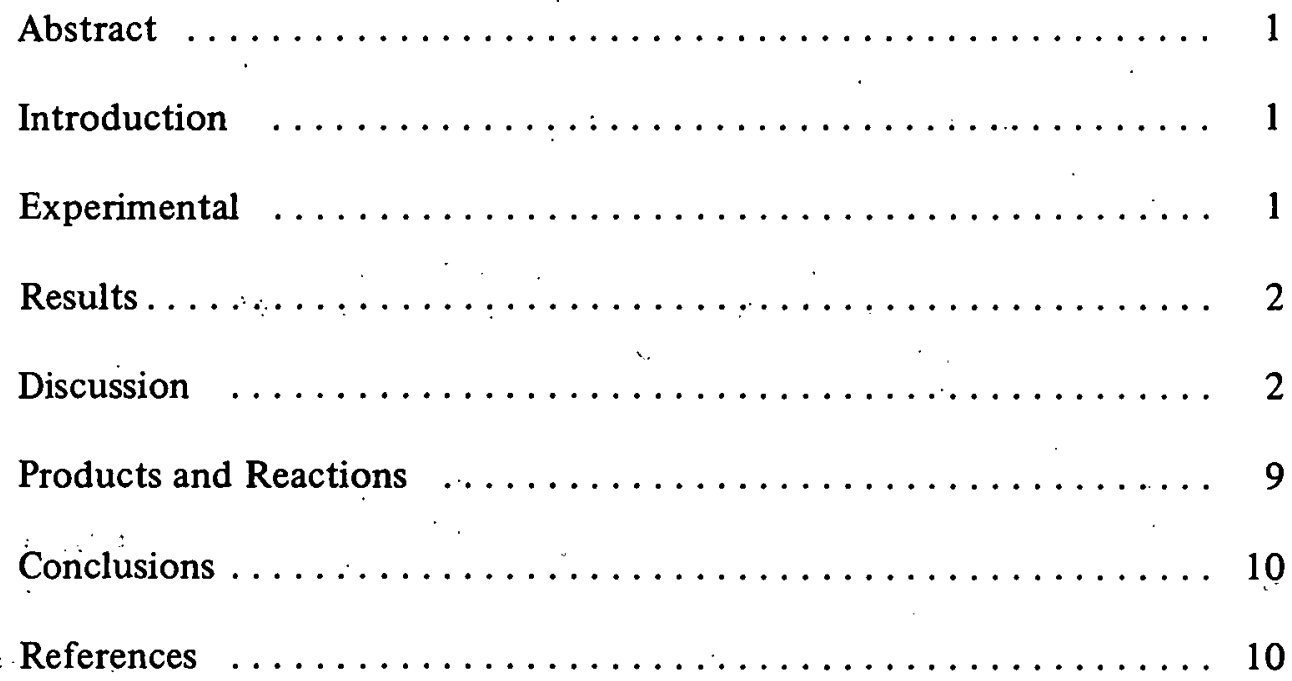


RFP-2919

\title{
CORROSION OF DELTA PLUTONIUM
}

BY SYNTHETIC SEA WATER

\author{
A. E. Hodges, III and J. M. Haschke
}

\begin{abstract}
Tests have been performed to determine the corrosive nature of sea water on delta plutonium at $25^{\circ} \mathrm{C}$. Corrosion rates were determined by measuring the time dependence of mass loss at constant pressure and the time dependence of hydrogen evolution in a sealed vessel. Test coupons were completely immersed in a standard solution of synthetic sea water for periods ranging from $1 \mathrm{hr}$ to $144 \mathrm{hr}$. Weight loss measurements show that delta plutonium corrodes at an average rate of 5.01 $\mathrm{mg} /\left(\mathrm{cm}^{2} \cdot \mathrm{hr}\right)$ while hydrogen is formed at an average rate of $1.6 \times 10^{-5} \mathrm{~mol} /\left(\mathrm{cm}^{2} \cdot \mathrm{hr}\right)$. The corrosion process is a hydrolysis reaction that produces hydrated plutonium(IV) nxide and hydrogen. The reaction apparently occurs along the grain boundaries of the metal.
\end{abstract}

\section{INTRODUCTION}

Considerable concern has been expressed regarding the possibility of a closed system that contains a subcritical mass of plitonninm heing assirently ruptured, totally immersed, and filled with sea water. Would the plutonium corrosion products significantly change the physical geometry of the plutonium to create a critical nuclear configuration? Secondly, how much time would there be for recovering the system before a self-sustaining nuclear reaction occurred?

Before either of these questions can be answered, it is necessary to establish the corrosion rate of delta plutonium in sea water. To acquire this information, corrosion studies involving delta plutonium coupons immersed in a synthetic sea water solution were conducted in accordance with NACE* Standard Method TM-01-69. Special corrosion tests also were performed which were designed to determine the rate of hydrogen production during the corrosion process.
TABLE 1. Components of a Standard Sea Water Solution (prepared according to ASTM D-1141-52)

\begin{tabular}{lrl}
\multicolumn{1}{c}{ Material } & $\mathrm{g} / \ell$ & wt \% \\
$\mathrm{NaCl}$ & 24.538 & 2.39 \\
$\mathrm{MgCl}_{2} \cdot 6 \mathrm{H}_{2} \mathrm{O}$ & 11.101 & 1.08 \\
$\mathrm{Na}_{2} \mathrm{SO}_{4}$ & 4.750 & 0.46 \\
$\mathrm{CaCl}_{2}$ & 1.160 & 0.11 \\
$\mathrm{KCl}$ & 0.690 & 0.07 \\
$\mathrm{NaHCO}_{3}$ & 0.200 & 0.02 \\
$\mathrm{KBr}$ & 0.100 & 0.01 \\
$\mathrm{H}_{3} \mathrm{BO}_{3}$ & $n n 3 n$ & 0.003 \\
$\mathrm{SrCl}$ & 0.040 & 0.004 \\
$\mathrm{NaF}$ & 0.003 & 0.0003
\end{tabular}

NOTE: Density of sea water equals $1.025 \mathrm{~g} / \mathrm{cm}^{3}$ at $15^{\circ} \mathrm{C}$.

\section{EXPERIMENTAL}

The sea water corrosion studies were conducted with delta plutonium coupons, with each coupon having a surface area of approximately $6.48 \mathrm{~cm}^{2}$. Each test coupon was totally immersed in a synthetic solution of sea water (see Table 1), which was prepared in accordance with Formula A of ASTM* Standard D-1141-52. The corrosion rate was obtained by removing corrosion products and measuring the weight loss of the sample after a specified time interval. Before the tests began, the coupons were cleaned of all previously accumulated oxide and foreign residues. This was accomplished in three steps. Each coupon was (1) brushed with a fine wire stainless steel brush, (2) uniformly abraded with 120-grit silicon paper, and (3) solvent-cleaned in 1,1,1-trichloroethane followed by air drying. The clean coupons were then weighed to the nearest $0.1 \mathrm{mg}$ and immersed in $100 \mathrm{ml}$ of the synthetic sea water solution. Storage periods

\footnotetext{
*National Association of Corrosion Engineers.
}

\footnotetext{
*American Society for Testing and Materials.
} 
ranged from $1 \mathrm{hr}$ to $144 \mathrm{hr}$. At the conclusion of each storage period, several coupons were removed from the sea water solution and were air dried. A stainless steel wire brush was then used to remove any loose corrosion products which may have adhered to the coupon surfaces. The weight loss due to corrosion was then determined by reweighing each of the coupons to the nearest 0.1 mg. Although some of the plutonium metal was also removed by the wire brush, previous corrosion studies indicate that this weight loss is generally less than $10 \mathrm{mg}$ per coupon and can be disregarded during this study.

The corrosion test used to measure the rate of hydrogen evolution was performed by immersing two, clean, delta plutonium coupons (also weighed to the nearest $0.1 \mathrm{mg}$ ) in $25 \mathrm{ml}$ of the sea water solution. That quantity of solution was contained in each of two, sealed, 50-ml stainless steel pressure vessels equipped with 0 - to 100 -psig pressure gauges. Both pressure vessels were stored at ambient temperature for a total of $49 \mathrm{hr}$. During this time, measurements of the pressure buildup resulting from hydrogen evolution were conducted on a regular basis. After $49 \mathrm{hr}$, both coupons were removed from the pressure vessels, recleaned, and reweighed in the manner previously described.

\section{RESULTS}

Results of the corrosion studies indicate that sea water can cause serious damage to delta plutonium coupons in short periods of time (less than $12 \mathrm{hr}$ ). The resulting corrosion products, which appeared as dark, bluish-green solids, began to accumulate almost immediately. Corrosion occurred so rapidly that cracking and flaking from the density change in the corrosion products occurred in less than 30 min. When these corrosion products were removed, pronounced pits were also found in the surfaces of the plutonium coupons. A summary of weight-loss corrosion data for each test coupon can be found in Table 2. An analysis of the data reveals that corrosion of the delta plutonium coupons proceeded at a relatively constant rate during the first 80 hours of the test. (See Figure 1.) However, during the final hours of the study, a decrease in the corrosion rate occurred. Significant amounts of gaseous hydrogen were also generated during the sea water corrosion of plutonium. Hydrogen pressure measurements, which were made with the pressure vessels, indicate that hydrogen evolved at an average rate of $1.6 \times 10^{-5} \mathrm{~mol} /\left(\mathrm{cm}^{2} \cdot \mathrm{hr}\right)$. (See Figure 2.) Weightchange evolutions of the two coupons used for these measurements are found in Table 3.

\section{DISCUSSION}

To understand the mechanism controlling sea water corrosion of delta plutonium, several mathematical tests have been conducted using accumulated data. A determination was sought as to whether the weight loss incurred by the coupons listed in Table 2 occurred as a result of a corrosion process controlled by the diffusion of water across an increasing product layer. For this reason, a parabolic rate test for such a process was performed. When the average corrosion $\left(\mathrm{mg} / \mathrm{cm}^{2}\right)$ is graphed as a function of the square root of the elapsed time, a non-linear plot results. This non-linearity indicates that corrosion of delta plutonium coupons is not diffusion controlled.

Test results suggest that the corrosion may actually be constant with time. If the rate of corrosion is constant, then change in the average corrosion rates (see uncorrected data in Table 4), when plotted as a function of the median time, should rcsult in a linear plot with a zero slope (see uncorrected data, Figure 3). A least-squares linear regression of this rate data yields a correlation coefficient $(R)$ of 0.89504; however, the negative slope indicates that the apparent rate is actually decreasing with time. The decreasing rate may be attributed to one of several conditions inherent to the experiment. It is possible that the rate of corrosion is in some manner dependent upon either the salt concentration of the solution or on the hydrogen pressure in the free volume (about $25 \mathrm{~cm}^{3}$ ) above the sea water solution. Since detectable quantities of chloride or other ions from the salt solution were not found in the corrosion products, the concentration of the salt solution was essentially constant throughout the test and the decreasing rate cannot be attributed to a solution change.

If the decreasing rate results from a buildup of product hydrogen, then the rate at which hydrogen is produced should decrease as time and pressure 
RFP-2919

TABLE 2. Corrosion Summary of Delta Plutonium in Sea Water at $23^{\circ} \mathrm{C}$

\begin{tabular}{|c|c|c|c|c|c|c|c|}
\hline \multicolumn{2}{|c|}{ Coupon Weight (g) } & \multirow{2}{*}{$\begin{array}{c}\text { Total Weight Loss } \\
\text { (g) }\end{array}$} & \multirow{2}{*}{$\begin{array}{l}\text { Time } \\
\text { (hr) }\end{array}$} & \multirow{2}{*}{$\begin{array}{l}\text { Average Corrosion } \\
\left(\mathrm{mg} / \mathrm{cm}^{2}\right)\end{array}$} & \multirow{2}{*}{$\begin{array}{l}\text { Corrosion } \\
\text { Penetration } \\
(\mu \mathrm{m})\end{array}$} & \multirow[b]{2}{*}{$\mu \mathrm{ph} *$} & \multirow{2}{*}{$\begin{array}{c}\text { Average } \\
\mu \mathrm{ph}\end{array}$} \\
\hline Initial & Final & & & & & & \\
\hline 4.9687 & 4.9162 & 0.0525 & 1 & & 5.08 & 5.08 & \\
\hline 4.9929 & 4.9380 & 0.0549 & 1 & 8.3 & 5.28 & 5.28 & 5.18 \\
\hline 5.1341 & 5.0806 & 0.0535 & 1 & & 5.17 & 5.17 & \\
\hline 4.8592 & 4.7761 & 0.0831 & 2 & & 8.04 & 4.02 & \\
\hline 4.3058 & 4.2082 & 0.0976 & 2 & & 9.44 & 4.72 & \\
\hline 5.3221 & 5.2211 & 0.1010 & 2 & 14.7 & 9.77 & 4.89 & 4.62 \\
\hline 4.9410 & 4.8407 & 0.1003 & 2 & & 9.70 & 4.85 & \\
\hline 4.3956 & 4.2381 & 0.1575 & 4 & & 15.23 & 3.81 & \\
\hline 4.9663 & 4.8110 & 0.1553 & 4 & 25.8 & 15.02 & 3.75 & 4.05 \\
\hline 5.3742 & 5.1846 & 0.1896 & 4 & & 18.33 & 4.58 & \\
\hline 4.6389 & 4.2941 & 0.3448 & 8 & & 33.34 & 4.17 & \\
\hline 4.9804 & 4.6431 & 0.3373 & 8 & 47.8 & 32.62 & 4.08 & 3.75 \\
\hline 4.5939 & 4.3460 & 0.2479 & 8 & & 23.97 & 3.00 & \\
\hline 4.9162 & 4.1267 & 0.7895 & 18 & & 76.34 & 4.24 & 3.90 \\
\hline 4.6331 & 3.9698 & 0.6633 & 18 & 112.1 & 64.14 & 3.56 & \\
\hline 4.7214 & 3.7662 & 0.9552 & 24 & & 92.37 & 3.85 & \\
\hline 5.0279 & 4.0844 & 0.9435 & 24 & 143.8 & 91.24 & 3.80 & 3.76 \\
\hline 4.6137 & 3.7161 & 0.8976 & 24 & & 86.80 & 3.62 & \\
\hline 5.1514 & 3.1974 & 1.9540 & 48 & & 188.95 & 3.94 & \\
\hline 5.2628 & 3.6237 & 1.6391 & 48 & 263.7 & 158.50 & 3.30 & 3.44 \\
\hline 5.3373 & 3.8031 & 1.5342 & 48 & & 148.36 & 3.09 & \\
\hline 4.9457 & 2.6274 & 2.3183 & 70 & . & 224.18 & 3.20 & \\
\hline 5.1426 & 2.7588 & 2.3843 & 70 & & 230.56 & 3.29 & \\
\hline 5.3146 & 3.0143 & 2.3003 & 70 & 362.8 & 222.44 & 3.18 & 3.25 \\
\hline 4.2223 & 1.8208 & 2.4015 & 70 & & 232.23 & 3.32 & \\
\hline 4.6318 & 1.8407 & 2.7911 & 95 & & 269.90 & 2.84 & \\
\hline 4.5513 & 1.6394 & 2.9119 & 95 & 440.1 & $281: 58$ & 2.96 & \\
\hline 5.1884 & 1.8270 & 3.3614 & 119 & & 325.05 & 2.73 & \\
\hline 5.1860 & 2.0535 & 3.1325 & 119 & 493.9 & 302.91 & 2.55 & 2.60 \\
\hline 5.3188 & 2.2115 & 3.1073 & 119 & & 300.48 & 2.53 & \\
\hline 5.2520 & 1.4914 & 3.8606 & 143 & & 373.32 & 2.61 & \\
\hline 5.0996 & 1.4078 & 3.6918 & 143 & 560.9 & 345.04 & 2.41 & 2.46 \\
\hline 4.6781 & 1.2600 & 3.4181 & 143 & & 330.53 & 2.31 & \\
\hline
\end{tabular}

increase. Figure 4 shows a graph of the average hydrogen evolution rate as a function of time. With the exception of the first two or three hours of the test (where accurate measurement of the pressure. change was difficult), the rate of hydrogen genera- tion is constant. It can be safely assumed that, because the rate of hydrogen production is relatively constant, the corrosion rate of delta plutonium coupons is not dependent upon hydrogen pressure above the sea water solution. 


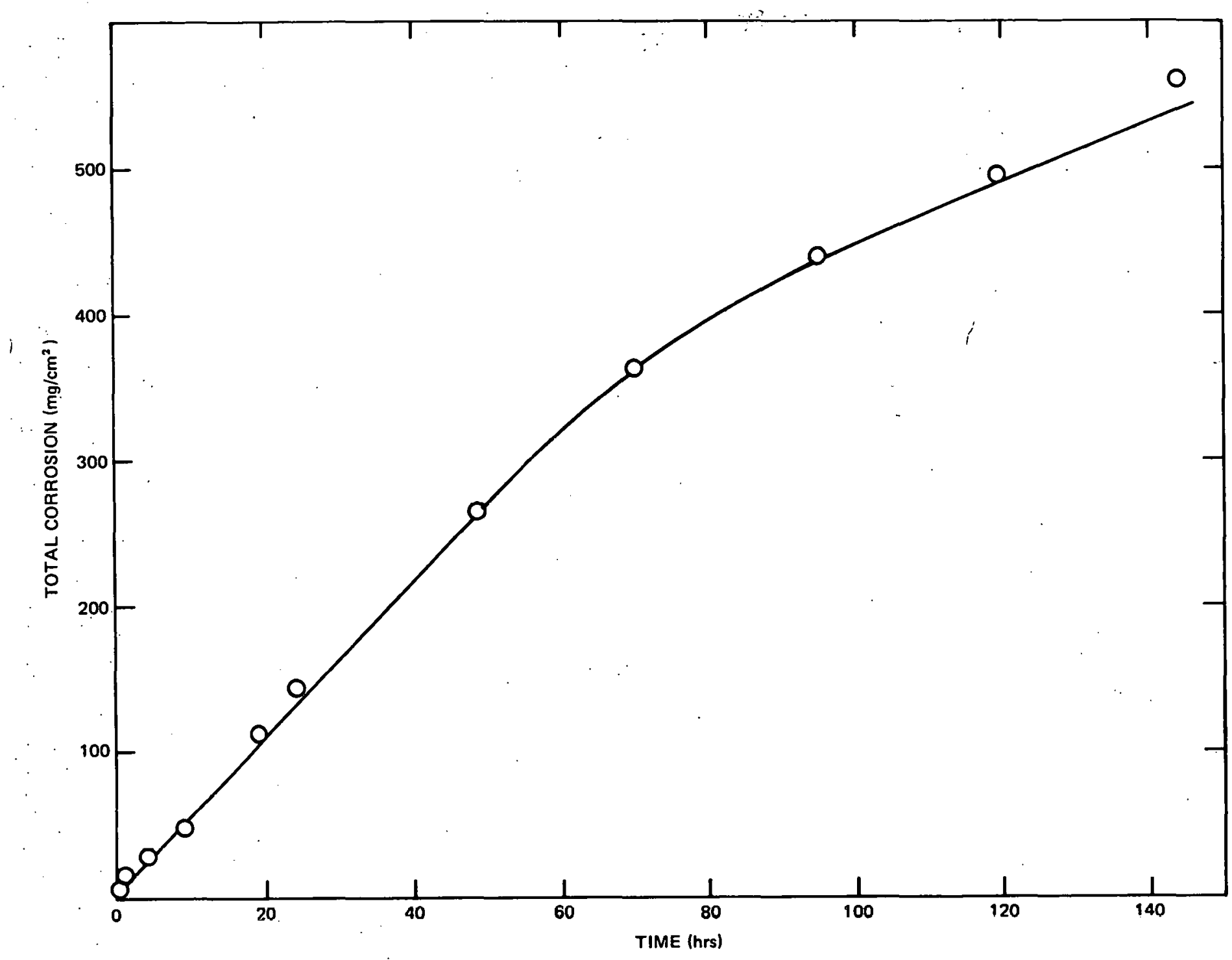

FIGURE 1. Corrosion of Delta Plutonium in Salt Water

The remaining condition (the most probable) that may affect the corrosion rate of delta plutonium coupons occurs when the actual surface area of the coupons becomes seriously reduced by the corrosion process. After about $80 \mathrm{hr}$ of testing, approximately $50 \%$ of the coupon mass has been lost. To account for the change in the actual surface area, the type of corrosion must be considered. From visual observations it can be seen that sea water corrodes by a pitting process. Therefore, the actual location of the corrosive attack probably occurs along the grain boundaries of the metal. If this occurs, then the surface area of the coupon is the sum of the surface areas of all plutonium grains. If the average grain size is constant throughout the sample, the plutonium surface area is proportional to the coupon volume. As corrosion progresses, and the coupon volume decreases, both the actual surface area and the measured corrosion rate are reduced. If the actual surface area is directly proportional to the coupon volume, and therefore to its mass, a correction can be made to account for the decreasing surface area. This correction can be made by multiplying the initially geometric surface 
RFP-2919

FIGURE 2. Hydrogen Evolution During Sea Water Corrosion of Delta Plutonium

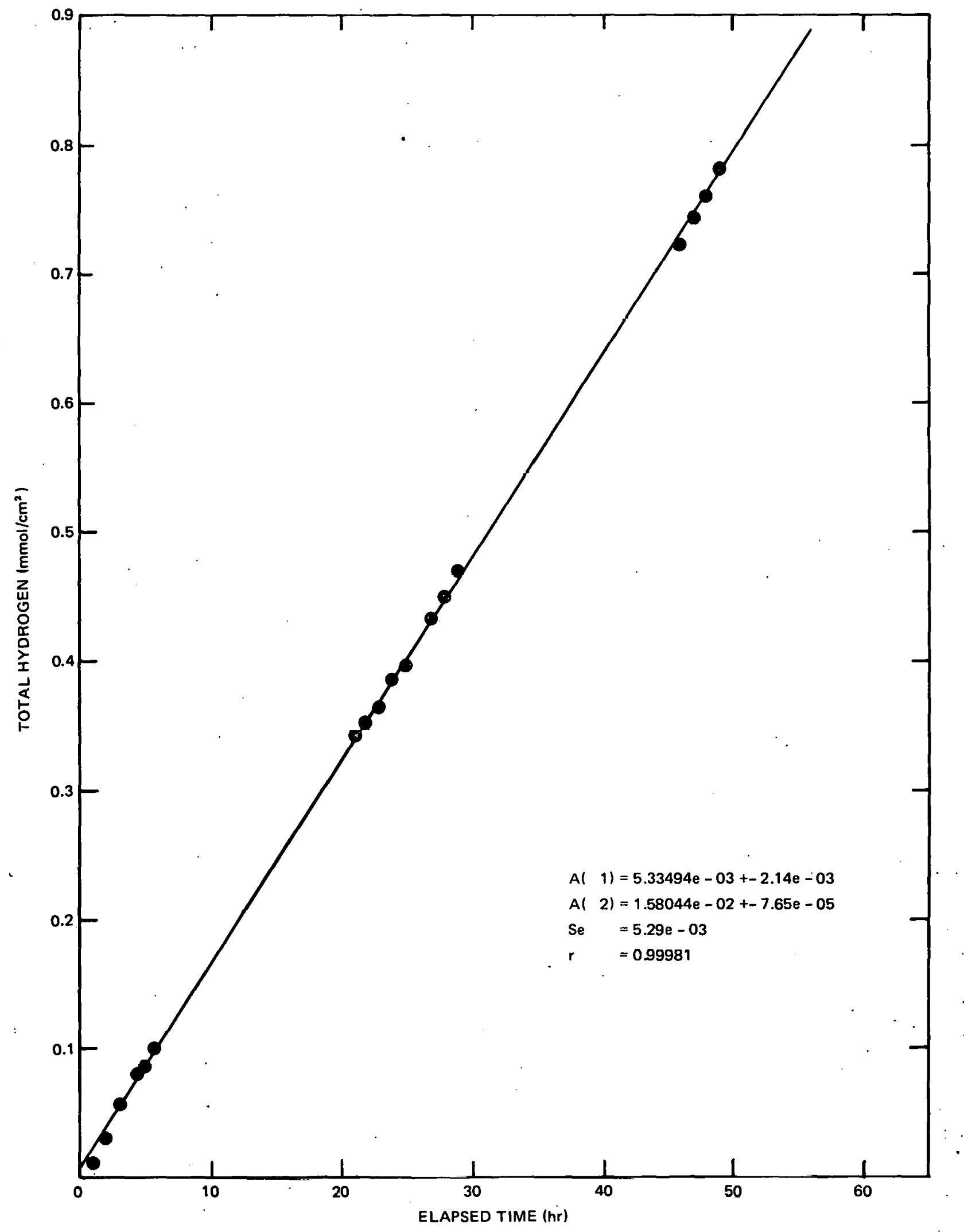


TABLE 3. Summary of Corrosion Data of Coupons Used in the Hydrogen Evolution Studies

$\begin{array}{cccccccccc}\begin{array}{c}\text { Total } \\ \text { Time } \\ (\mathrm{hr})\end{array} & \begin{array}{c}\text { Initial } \\ \text { Weight } \\ (\mathrm{g})\end{array} & \begin{array}{c}\text { Final } \\ \text { Weight } \\ (\mathrm{g})\end{array} & \begin{array}{c}\text { Total } \\ \text { Weight } \\ \text { Loss } \\ (\mathrm{g})\end{array} & \begin{array}{c}\text { Average } \\ \text { Corrosion } \\ \left(\mathrm{mg} / \mathrm{cm}^{2}\right)\end{array} & \begin{array}{c}\text { Average } \\ \text { Corrosion } \\ \text { Rate } \\ {\left[\mathrm{mg} /\left(\mathrm{cm}^{2} \cdot \mathrm{hr}\right)\right]}\end{array} & \begin{array}{c}\text { Hydrogen } \\ \text { Pressure }\end{array} & \begin{array}{c}\text { Hydrogen } \\ \text { Observed } \\ (\mathrm{mol})\end{array} & \begin{array}{c}\text { Hydrogen } \\ \text { Expected* } \\ \left(\mathrm{mol}^{*}\right)\end{array} \\ 4 & 4.5688 & 2.4643 & 2.1045 & 324.8 & 6.63 & 82 & 0.0057 & 0.0176 \\ 49 & 4.6749 & 3.0908 & 1.5841 & 244.5 & 4.99^{\circ} & 64 & 0.0044 & 0.0133\end{array}$

*Moles of hydrogen calculated from plutonium weight loss data, assuming the following ideal equation: $\mathrm{Pu}+4 \mathrm{H}_{2} \mathrm{O} \rightarrow \mathrm{Pu}(\mathrm{OH})_{4}+2 \mathrm{H}_{2}$

TABLE 4. Summary of Median Corrosion Rates

\begin{tabular}{|c|c|c|}
\hline $\begin{array}{l}\text { Median } \\
\text { Time } \\
\text { (hr) }\end{array}$ & $\begin{array}{l}\text { Avèrage Corrosion Rates } \\
\text { at Median 'l'ime From } \\
\text { Uncorrected Surface Area Data } \\
{\left[\mathrm{mg} /\left(\mathrm{cm}^{2} \cdot \mathrm{hr}\right)\right]^{\mathrm{a}}}\end{array}$ & $\begin{array}{l}\text { Average Corrosion Rates } \\
\text { at Median 'lime Using } \\
\text { Corrected Surface Area Data } \\
\qquad\left[\mathrm{mg} /\left(\mathrm{cm}^{2} \cdot \mathrm{hr}\right)\right]^{\mathrm{b}}\end{array}$ \\
\hline 0.5 & 8.3 & 8.3 \\
\hline 1.5 & 6.4 & 6.4 \\
\hline 3.0 & 5.6 & 5.8 \\
\hline 6.0 & 5.5 & 5.8 \\
\hline 13.0 & 6.4 & 6.2 \\
\hline .21 .0 & $5: 3$ & 8.3 \\
\hline 36.0 & 5.0 & 6.9 \\
\hline 59.0 & 4.5 & 7.6 \\
\hline 82.5 & 3.1 & 4.5 \\
\hline 107.0 & 2.2 & 8.5 \\
\hline 131.0 & 2.8 & 9.3 \\
\hline \multicolumn{3}{|c|}{$\begin{array}{l}\text { a. The average for the uncorrected corrosion rates is } 5.01 \mathrm{mg} /\left(\mathrm{cm}^{2} \cdot \mathrm{hr}\right) \\
\text { with a standard deviation of } 1.79 \text {. } \\
\text { b. The average for the corrected corrosion rates is } 7.02 \mathrm{mg} /\left(\mathrm{cm}^{2} \cdot \mathrm{hr}\right) \\
\text { with a standard deviation of } 1.42 \text {. }\end{array}$} \\
\hline
\end{tabular}

area by the percentage of the coupon mass remaining, and using that value in the rate calculation. A summary of the average corrected and uncorrected corrosion rates is given in Table 4 . The corrected data indicate that, if the quantity of plutonium remains essentially constant, an average corrosion rate of about $7.0 \mathrm{mg} /\left(\mathrm{cm}^{2} \cdot \mathrm{hr}\right)$ is to be expected for plutonium immersed in sea water. A graph of the corrected corrosion data is also found in Figure 3.
From the results in Table 3, it can be seen that there is a significant difference between the moles of hydrogen observed and moles of hydrogen predicted. This observation also supports the conclusion that the actual corrosion is occurring primarily along the grain boundaries of the metal. If all of the weight loss observed was due strictly to the reaction of the plutonium metal with sea water, then considerably larger quantities of hydrogen could be expected. The experimental 


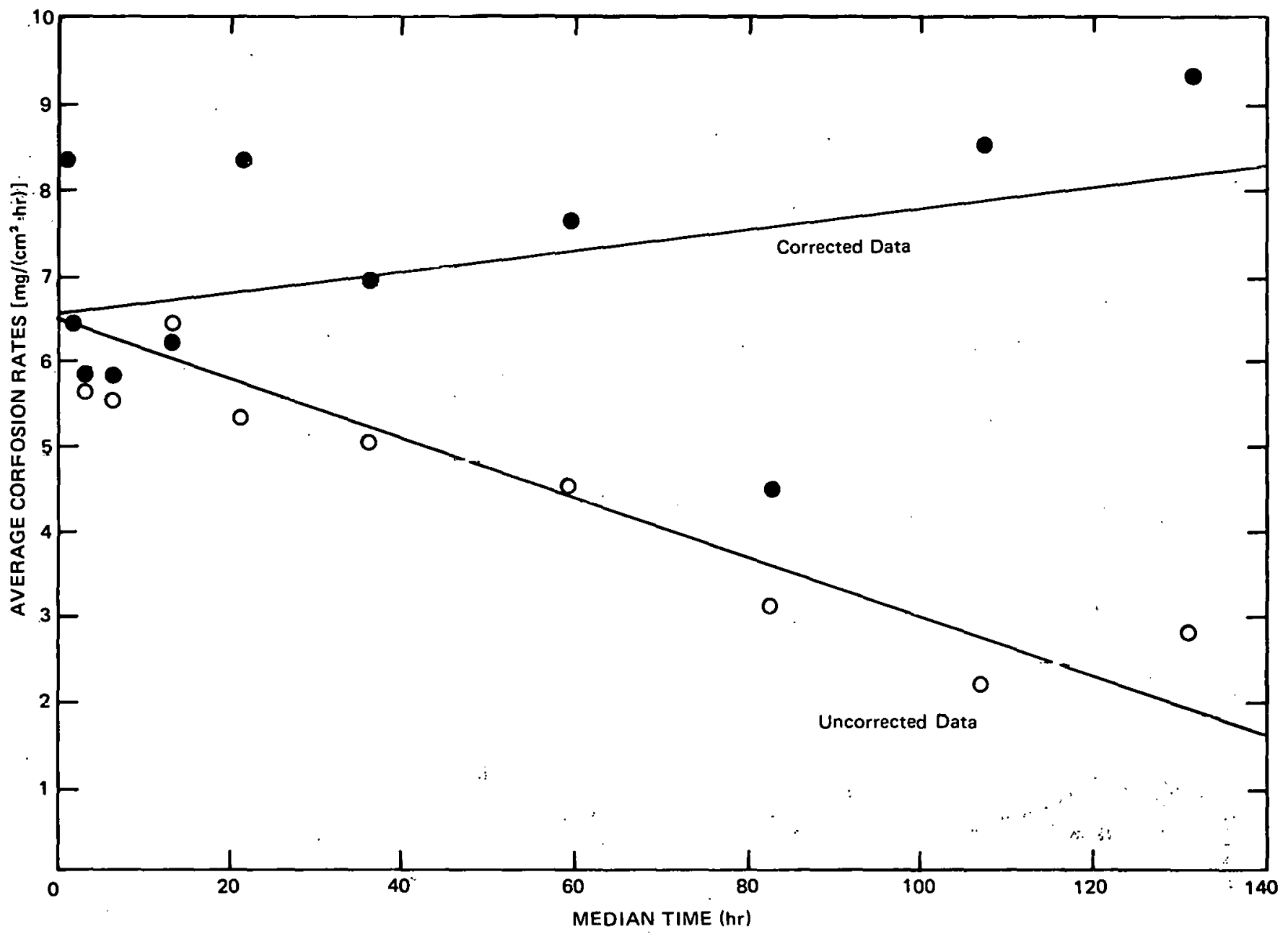

FIGURE 3. Summary of Corrected and Uncorrected Corrosion Rates

mass loss rate and the calculated quantity of hydrogen are probably higher than the actual values. If corrosion occurs along grain boundaries, particles of metal are probably lost from the surface.

Although the actual corrosion rate of the delta plutonium coupons is not constant because of the decreasing surface area, the corrosion can still be adequately formulated. The instantaneous rate is described as follows:

$$
-\frac{d N}{d t}=A_{1}+A_{2} t
$$

where $\mathrm{N}$ is the residual plutonium $\left(\mathrm{mg} / \mathrm{cm}^{2}\right), \mathrm{t}$ is the elapsed time, and $A_{1}$ and $A_{2}$ are constants. After integration, Equation 1 becomes

$$
\text { No }-N=A_{1} t+A_{2} t^{2}
$$

where No is the initial plutonium weight, and the quantity No $-\mathrm{N}$ is the total corrosion $\left(\mathrm{mg} / \mathrm{cm}^{2}\right)$ after a given time. If the linear regression values of $A_{1}$ and $A_{2}$ obtained from the uncorrected data listed in Table 4 are substituted into Equation 2, corrosion of the delta plutonium coupons can be expressed by Equation 3 .

$$
\text { total corrosion }=\mathrm{No}-\mathrm{N}=6.43 \mathrm{t}-0.01705 \mathrm{t}^{2}
$$

Using Equation 3, a comparison can be made between the amount of observed corrosion and the amount of corrosion which would be expected after a specified time. (See Table 5.). With the exception of the first data points, the calculated values agree with the observed values. The higher values which are obtained for the initial points in Table 5 can be attributed to the extremely clean and thus more 
FIGURE 4. Rate Change of Hydrogen Generation Due to Corrosion of Delta Plutonium by Sea Water

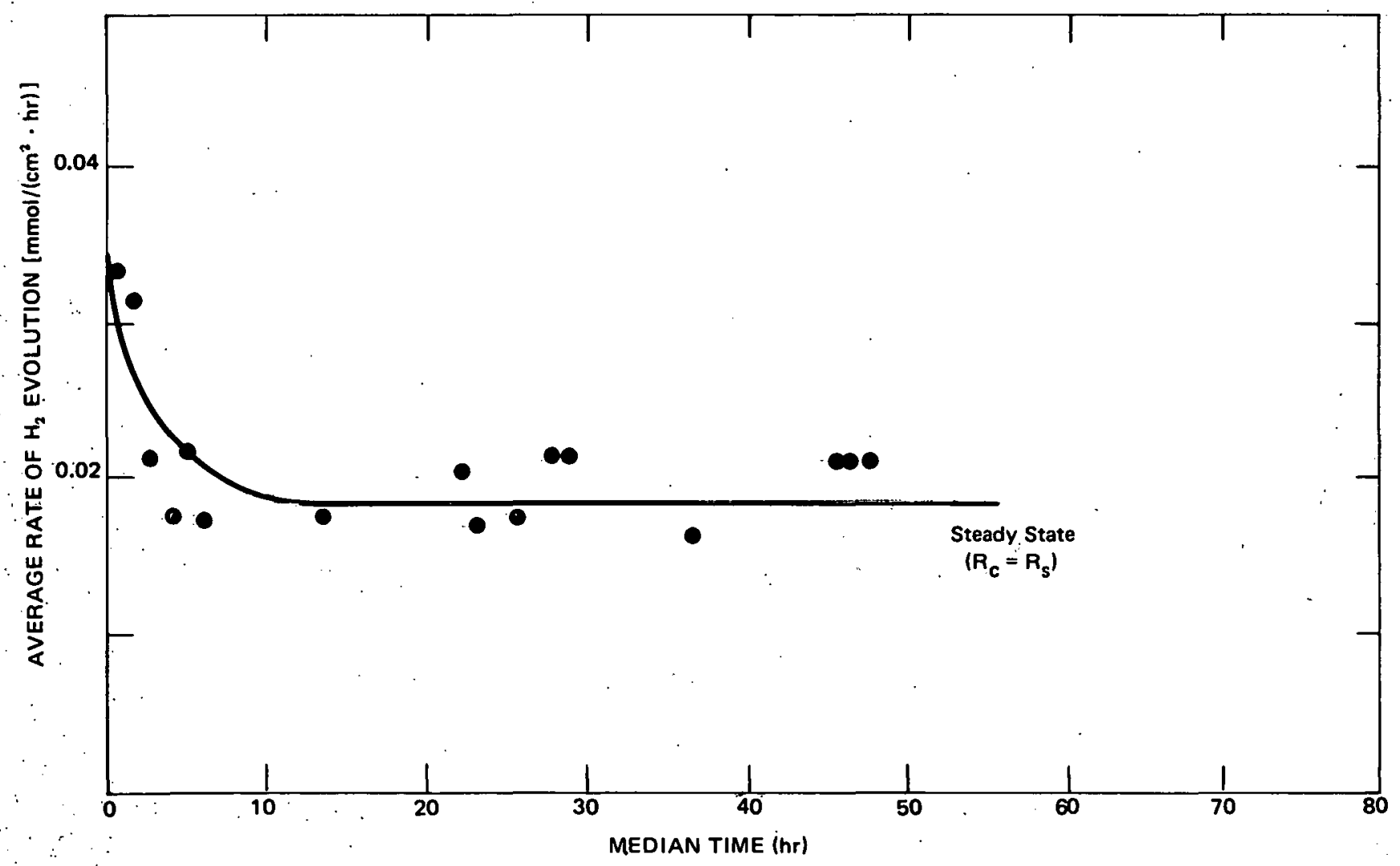


TABLE 5. Summary of Observed and Calculated Corrosion

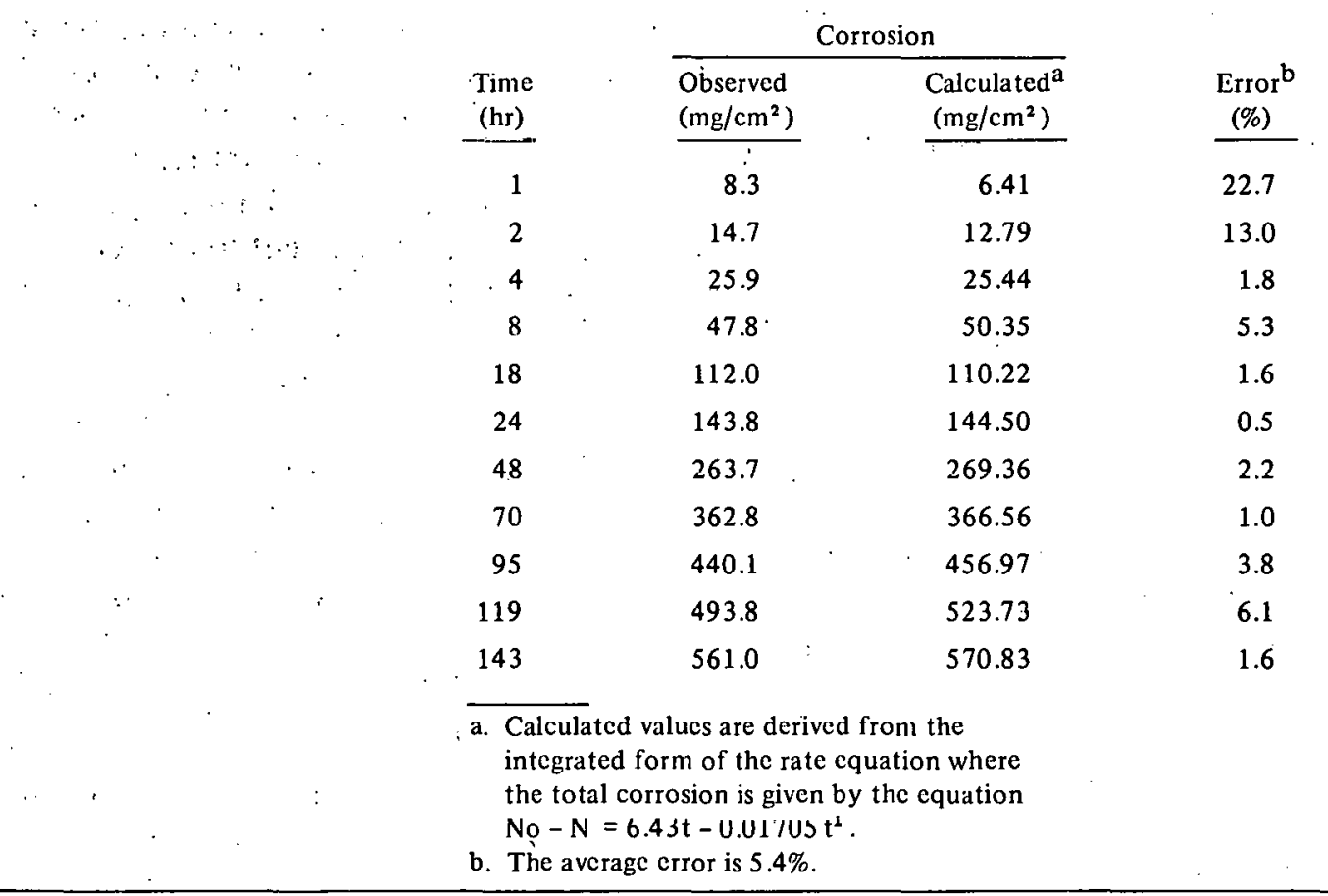

reactive condition of the coupons at the beginning of the corrosion tests. Similar behavior also is observed in the initial points in Figure 4.

\section{PRODUCTS AND REACTIONS}

During the corrosion of delta plutonium by sea water, a dark, bluish-green residue accumulates on and around the sample coupons. The residue, while wet, has a granular texture which is attributed to the presence of small particles of unreacted plutonium metal. The greenish color suggests that the non-granular portions of the residue is a hydroxide of the tetravalent plutonium $\left[\mathrm{Pu}(\mathrm{OH})_{4} \cdot \mathrm{X} \mathrm{H}_{2} \mathrm{O}\right]$, which is known to precipitate from a solution of $\mathrm{pH} \mathrm{8.}$ A thermogravimetric analysis (TGA) of the residue indicates that in the temperature range between 25 and $250^{\circ} \mathrm{C}$, a weight loss of $17.5 \%$ occurs. If it is assumed that the composition of the residue material is hydrated oxide, the TGA value is in good agreement with the theoretical weight loss of $17.63 \%$ calculated for $\mathrm{Pu}(\mathrm{OH})_{4} \cdot \mathrm{H}_{2} \mathrm{O}$. However, since the residue probably contains free metal, it is safe to assume that a greater number of hydrated waters are associated with the plutonium hydroxide.

An analysis of the sea water solution following the corrosion test revealed a plutonium concentration . of $1.4 \times 10^{-5} \mathrm{~mol} / \ell$. This value is orders of magnitude greater than the solubility of $1 \times 10^{-30}$ $\mathrm{mol} / \ell$ calculated for $\mathrm{pH} 8$ water using an average. $\mathrm{K}_{\mathrm{sp}}$ value of $10^{-54}$ for hydroxide. ${ }^{1}$ However, $\mathrm{Pu}(\mathrm{OH})_{4}$ has a tendency to form colloidal polymers, which can account for the higher plutonium concentration in the aqueous phase. ${ }^{1}$

From the information just presented, it is reasonable to conclude that the corrosion of delta plutonium is an electrochemical reaction described by the following half cell and net reactions:

$$
\begin{aligned}
& \text { 4. } \mathrm{H}_{2} \mathrm{O}+4 \mathrm{e}^{-} \rightarrow 4 \mathrm{OH}^{-}+2 \mathrm{H}_{2}(\mathrm{~g}) \\
& \mathrm{Pu}(\mathrm{s}) \rightarrow \mathrm{Pu}^{4}+4 \mathrm{e}^{-} \\
& \mathrm{Pu}(\mathrm{s})+4 \mathrm{H}_{2} \mathrm{O} \rightarrow \mathrm{Pu}(\mathrm{OH})_{4}(\mathrm{~s})+2 \mathrm{H}_{2}(\mathrm{~g})
\end{aligned}
$$


It is apparent that this hydrolysis is common to all plutonium-plus-water systems. The rate of the irreversible corrosion process is accelerated by increasing the concentration of ions in solution. Measurements of the corrosion rate of delta plutonium in typical tap water show that a net corrosion between 500 and $600 \mathrm{mg} / \mathrm{cm}^{2}$ is achieved after approximately $1800 \mathrm{hr}^{2}$ In sea water, the same amount of corrosion is reached in less than $150 \mathrm{hr}$. The mechanism of the electrochemical reaction process is not understood; nevertheless, it is reasonable to assume that the rates of electron transfer in the redox process are catalyzed by the presence of various ions, which act as electrolytes and/or bridging species. The corrosion rate in tap water is lower than in sea water because of the lower concentration of cataly tic species.

A qualitative comparison of the results for tap water ${ }^{2}$ and sea water suggest that the same corrosion mechanism is operative in both systems. The initially rapid corrosion rate in tap water decreases with time until-a constant corrosion rate is reached. A test of the data with the parabolic rate law shows that the rate decrease results from buildup of a product layer on the metal surface. The conștant exposure rate is attributed to the maintenance of a layer of constant average thickness resulting from flaking of the product. Observation of a constant rate during exposure to sea water suggests that a similar process is occurring; the initial formation of the layer is apparently so rapid in sea water that it cannot be detected.

\section{CONCLUSIONS}

Corrosion of delta plutonium by sea water apparently occurs at a rapid rate along the grain boundaries of the metal. As a result, large quantities of gaseous hydrogen and solid residues are generated, which leaves pitted plutonium surfaces. Without question, the rate of corrosion and subsequent hydrogen evolution is great enough to cause extensive damage to delta plutonium components immersed in sea water. For a large quantity of plutonium, the corrosion rate would be expected to be about 7 $\mathrm{mg} /\left(\mathrm{cm}^{2} \cdot \mathrm{hr}\right)$. This rapid corrosion would generate hydrogen with pressures great enough to partially displace the sea water from an inverted container and could lead to the possible hydriding of the exposed plutonium.

Although the conditions for changing a subcritical plutonium system to a critical nuclear configuration depends on numerous parameters, it is apparent that sea water corrosion and possible hydriding could seriously change the geometries of plutonium components in a very brief period.

\section{REFERENCES}

1. J. M: Cleveland. The Chemistry of Plutonium, Gordon and Breach Science Publishers, 1970.

2. A. E. Hodges, J. J. Reynolds, and J. M. Haschke. Corrosion of Delta Plutonium in Rocky Flats Tap Water, RFP-2891, Rockwell International, Rocky Flats Plant, Golden, Colorado, August 29, 1979. 